\title{
Notes on the origin and dating of the bone pyxides from the Sarmatian environment between the Don and the Prut
}

Vitalie Bârcă

\begin{abstract}
The object of this article is to discuss the bone pyxides discovered in the Sarmatian graves from the north and north-west of the Black Sea. The study, without being exhaustive, attempts a presentation of the graves where bone pyxides were identified, but also of the cultural environments where similar toiletry pieces were used. The conclusion is that bone pyxides in Sarmatian graves from the north and north-west Pontic territory are mainly Roman products. Nonetheless, it is not excluded that some pyxides are copies of the first, made in local workshops (north-Pontic). The author notes that all Sarmatian graves containing bone pyxides date, on the basis of grave goods, to the second half of the 1st - early/first decades of the 2 nd c. $\mathrm{AD}$. Furthermore, it is noted they are usually part of the grave group belonging to the new wave of Sarmatians arriving to the north-Pontic area starting with mid 1st c. $\mathrm{AD}$ from east of the Don and that in the second half of the 1 st - first decades of the 2 nd c. AD they form a well marked local cultural-chronological horizon. Last but not least, the author notes that pyxides are part of funerary features dating to the period of major inflow of Roman artifacts to the Sarmatian environment set between AD 60/70 - 120/130.
\end{abstract}

Keywords: the Sarmatians, pyxides, artifacts, imports, graves, the north Pontic area, the Roman Empire

Pyxides are toiletry objects, commonly cylindrical, rather well spread in the Graeco-Roman world, but also intensively used in other cultural environments. Over the course of the ancient times, pyxides were made of clay, metal, marble, alabaster, rarely of glass or plaster, to which add those in bone, widely spread and used (Sokol'skij 1971, 199; Béal and Feugère 1983, 115-116; Peters 1986, 68; Moshkova 1989, 188-189; Mordvintseva and Trejster 2007, I, 55-56; Bârcă 2017, 101 sqq.). However, the basic material used from the very beginning in the making of these pieces was wood (Sokol'skij 1971, 199) ${ }^{1}$. They are lidded, while in some metal specimens a fastening/hanging system to the belt/strap (cf. Bârcă 2017, 102) may be noted. Pyxides mainly served for preserving makeup paints, certain substances/powders used for embellishment or aromatic

1 For the analysis of a number of over 100 wood pyxides from territories north the Black Sea dated to the 5 th c. BC -4 th c. AD see pages 200-215. 
substances and rarely, mineral materials, resins or plants believed healing. The remains of these substances are occasionally found inside the pyxides. Most specimens from the Sarmatian environment of the first centuries AD are bonemade, yet there are also wood or metal specimens etc. For the making of bone pyxides in the ancient period elephant bones, large cattle and horses were used. Among the bone pieces from the Graeco-Roman world count also specimens decorated with depictions made in relief. Usually, these artifacts are attributes of female graves, but there are also cases when they were discovered in male graves (Sokol'skij 1971, 200; Gushchina and Zasetskaya 1994, 33) as well.

In the north-Pontic area, bone cylindrical pyxides were widely spread in the first two centuries $\mathrm{AD}$, although they were also used in the previous period (cf. Peters 1986, 68-70).

Bone pyxides are frequent in the first centuries $\mathrm{AD}$ in the Roman provincial environment (Davidson 1952, 136, Pl. 69, no. 965, 137, Pl. 70, no. 964; Alföldi 1957, 488, Pl. CXXXIV/14; Pleniscar-Gec 1972, Pl. CCX/6; Petru 1972, Pl. IX/26, XV/1, LXI/4, LXIV/4, LXVIII/24, XCV/13; Marangou 1976, no. 217, 125, Pl. 64/a, b; Goethert-Polaschek 1977, Pl. 3, 5, 9; Mackensen 1978, Pl. 76/2; Béal, and Feugère 1983,115-126; Groh 1990, 17-23; Groh 1994, 187-195; Bíró 1994, 41, 127, Pl. LI-LII; Deschler-Erb 1998, Band 27/1, 179-180, Pl. 4445, Band 27/2, 332-333; Bíró et al. 2012, 17, 95-98), yet they are often found among finds in Greek towns and their cemeteries from the north of the Black Sea (Ivanova 1955, 407, Fig. 2; Sokol'skij 1971, 209, Pl. XXIX/14-15; XXX/14; Peters 1986, 68-70, 143-145, 177, Pl. XIV; Medvedev 2009, 170, Fig. 3/3; Medvedev 2011, Fig. 3/1, 4/12 (originate in late ancient date graves); Zhuravlev and Lomtandze 2002, 77, cat. no. 289), the late Scythian environment of Crimea (Gushchina 1982, 26; Vysotskaya 1994, 98, 119, Pl. 5; Puzdrovskij 2007, 155156, Fig. 133/12-15, 135/1-8, 136/1-2, 6-7) and that Meotian (Marčenko and Limberis 2008, 309, cat. no. 177.3, 181.2, Pl. 185/3, 190/2). Because of the archaeological finds, dynamically on the rise, but also the publishing of the results of previous research, the number of pyxides increased, while new finds were reported in various cultural environments. Nevertheless, it must be noted that pyxides, either of bone, wood or metal are not very numerous in the Sarmatian environment ${ }^{2}$. This state of fact indicates, according to M. G. Mosh-

2 For wood pyxides in the Sarmatian environment we may mention the wood cylindrical specimen identified, among other wood wares, in T 4 G 4 from Olănești to the right of the Lower Dniester (Melyukova 1962, 204-205; Kurchatov and Bubulici 2003, 300, 301). Its body extremities were decorated with two incised lines and the lid with two concentric circles. A wood pyxide comes also from $\mathrm{T} 43$ discovered between the places of Kazanskaya and Tiflisskaya (Tbilisskaya) in the Kuban region (Gushchina and Zasetskaya 1994, 33, cat. no. 115, Pl. 12/115; Marčenko and Limberis 2008, 347, cat. no. 39 Pl. 68/7). 
kova, that Sarmatian women used them for keeping makeup paints, embellishment substances/powders etc., leather sachets or fiber materials, their remains being found quite often within graves (Moshkova 1989, 188).

In the area between the Don and the Prut such bone artifacts, either complete or fragmentary, were discovered in several Sarmatian graves (Fig. 9). Amongst count T 6 G 1 from the cemetery at Sladkovka, 1977 (Maksimenko 1998, 132, Fig. 55/13) (Fig. 2/3), T 2 G 1 at Novofilippovka (Simonenko 2008, 80, cat. no. 124.1, Pl. 136/4; Simonenko 2011, 174, cat. no. 11.1, Fig. 67/6) ${ }^{3}$ (Fig. 1/1), T 2 G 1 at Novofilippovka ${ }^{4}$ (Vyaz'mitina et al. 1960, 44, Fig. 27/4; Simonenko 2008, 80, cat. no. 125.2, Pl. 137/3; Simonenko 2011, 174, cat. no. 12.2), the eastern grave group (Fig. 1/2), T 18 from Akkermen' $\mathrm{II}^{5}$ (Vyaz'mitina et al. 1960,78, Fig. 64/4; Simonenko 2008, 80-81, cat. no. 128.1, Pl. 139/2a; Simonenko 2011, 176, cat. no. 17.1), the western grave group (Fig. 1/3), T IV from the eastern group of graves from Akkermen' $\mathrm{II}^{6}$ (Vyaz'mitina et al. 1960, 85, Fig. 68/6; Simonenko 2008, 81, cat. no. 130.3, Pl. 141/1e; Simonenko 2011, 177, cat. no. 19.3, Fig. 67/3) (Fig. 1/4), T 13 G 1 at Novo-Podkryazh ${ }^{7}$ (Kostenko 1977, 124; Moshkova 1989, 188, Pl. 80/14; Simonenko 2008, 60, cat. no. 37.1, Pl. 26/1; Simonenko 2011, 186, cat. no. 48.1, Fig. 67/1; Bârcă and Symonenko 2009, 178, Fig. 64/8) (Fig. 3/1), T 45 G 1 at Ust'-Kamenka ${ }^{8}$ (Fig. 3/2) (Kostenko 1993, 49, Fig. 16/32; Simonenko 2008, 64, cat. no. 63.3, Pl 48/2b; Simonenko 2011, 190-191, cat. no. 59.3, Fig. 67/2; Bârcă and Symonenko 2009, 178, Fig. 64/2), Tsvetna9 (Fig. 2/1) (Simonenko 2008, 70, cat. no. 87.4, Pl. 80/1; Simonenko 2011, 206, cat. no. 90.4, Fig. 67/5), Kovalevka, the Sokolova Mogila G 3 barrow grave ${ }^{10}$ (Fig. 2/2) (Kovpanenko 1986, 78-80, Fig. 82-83; Simonenko 2008, 75, cat. no. 99.9, Pl 107/3; Simonenko 2011, 223, cat. no. 110.8, Fig. 67/4; Bârcă and Symonenko 2009, 178, Fig. 64/3) to which adds that from T 424 G 2 at Krasnopolka (Simonenko 2008, 68, cat. no. 81, Pl. 165; Simonenko 2011, 194, cat. no. 68; Bârcă 2014a, 53-54), T 20 G 1 (Fig. 4/1-3) (Bârcă 2006, 161, 278, Fig. 7/3-5; Bârcă and Symonenko 2009, 178, Fig. 64/1) and T 27 G $1^{11}$ (Fig. 4/4) from Bădragii Vechi (Bârcă 2006, 161, 284, Fig. 17/5), and that in T 9

3 Body height $-3 \mathrm{~cm}$; lid diameter $3.4 \mathrm{~cm}$; midway body diameter $3 \mathrm{~cm}$; base diameter $-3.4 \mathrm{~cm}$.

${ }^{4}$ Height $-3.8 \mathrm{~cm}$; diameter $-3.4 \mathrm{~cm}$.

5 Height $-3.9 \mathrm{~cm}$; midway body diameter $-3.2 \mathrm{~cm}$.

6 Height $-4 \mathrm{~cm}$; lid diameter $-4 \mathrm{~cm}$; base diameter $4.1 \mathrm{~cm}$.

7 Pyxis height lid included $-6.7 \mathrm{~cm}$; lid diameter $-4.8 \mathrm{~cm}$.

8 Height $-5.8 \mathrm{~cm}$; midway body diameter $-3.4 \mathrm{~cm}$; lid height with elongated profiled knob included $-2.7 \mathrm{~cm}$.

9 Height $-3.2 \mathrm{~cm}$; lid diameter $-3 \mathrm{~cm}$; base diameter $-3.5 \mathrm{~cm}$.

${ }^{10}$ Height with lid included $-4.5 \mathrm{~cm}$; lid and base diameter $-3.5 \mathrm{~cm}$.

${ }^{11}$ Height $-6.2 \mathrm{~cm}$; diameter -3.3 and $4 \mathrm{~cm}$, base diameter $-3.8 \mathrm{~cm}$, lid diameter $-4.1 \mathrm{~cm}$. 


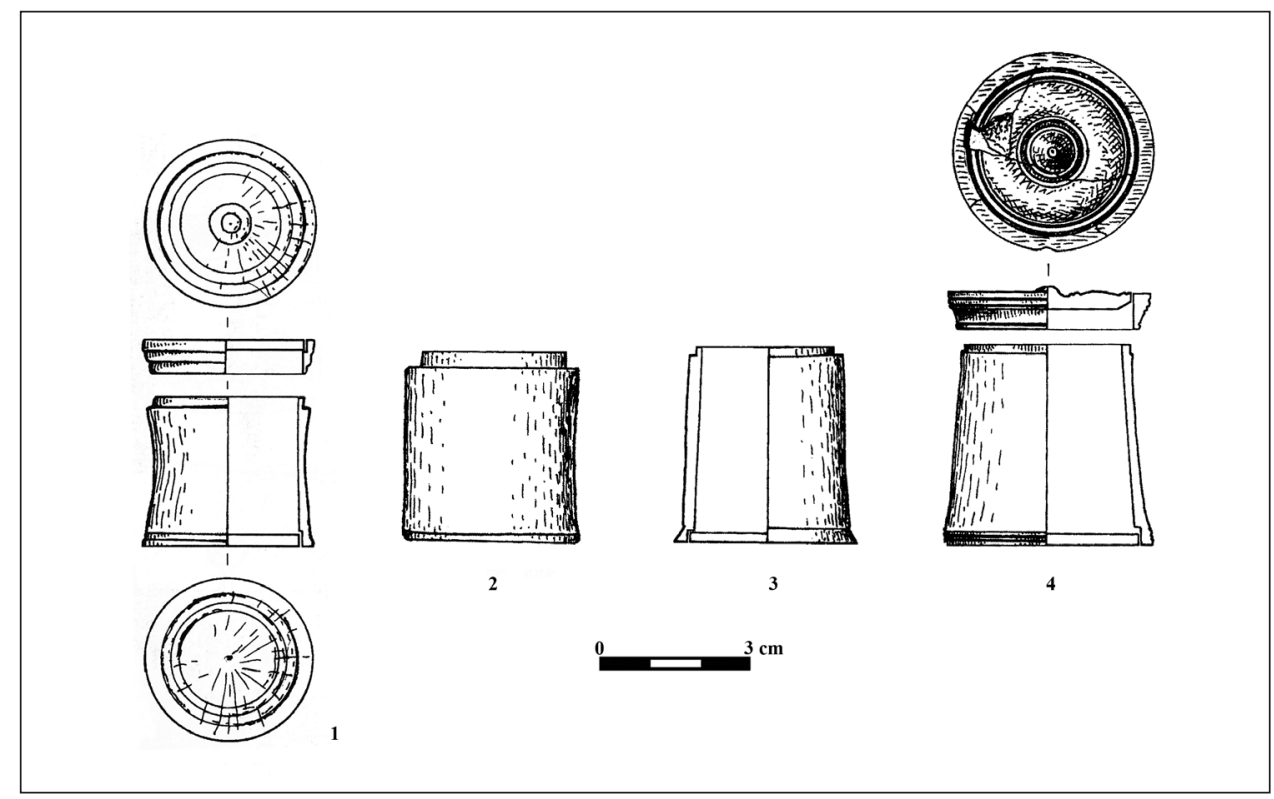

Fig. 1. Bone pyxides. 1. Novofilippovka (T 2 G 1); 2. Novofilippovka ( 2 G 1, eastern grave group); 3. Akkermen' II (T 18, western grave group); 4. Akkermen' II (T IV, eastern grave group) (after Simonenko 2008).

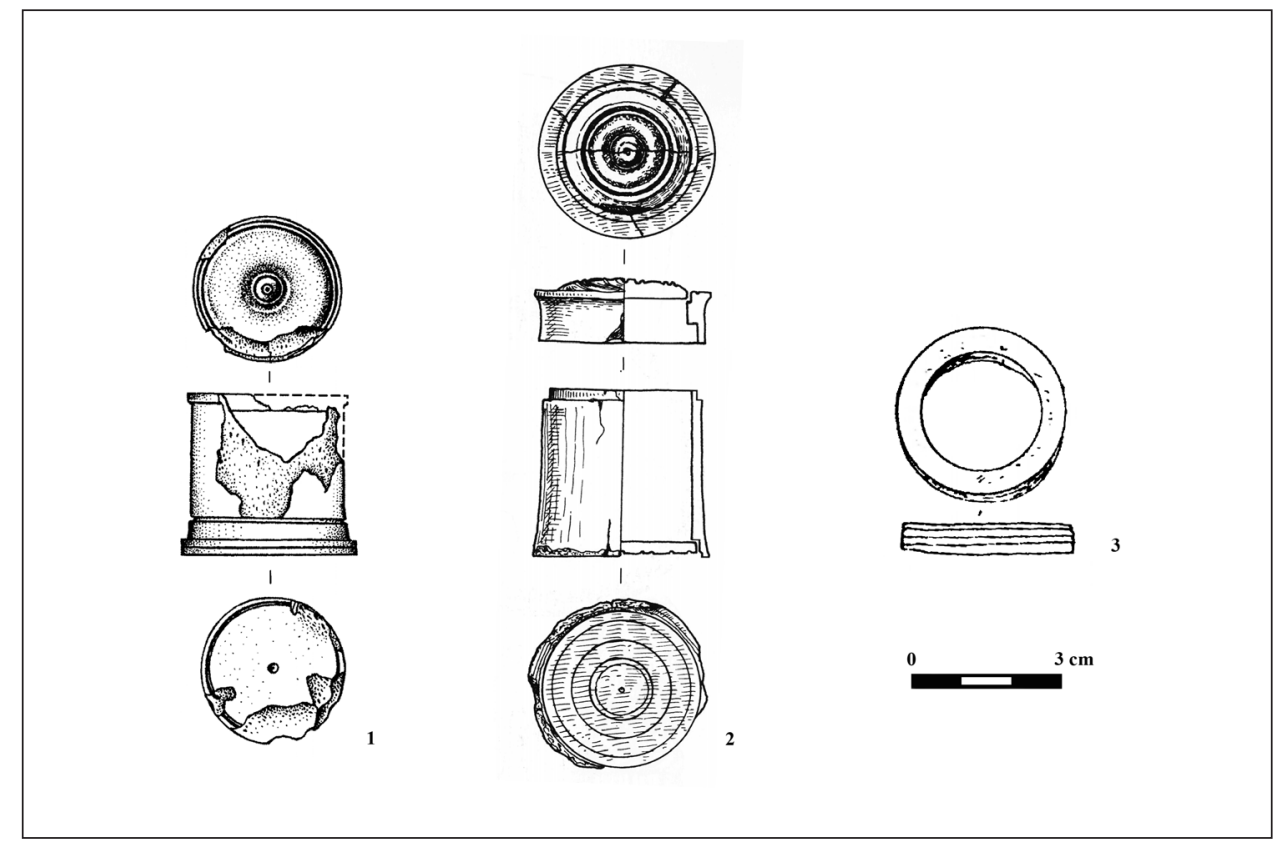

Fig. 2. Bone pyxides. 1. Tsvetna; 2. Kovalevka, Sokolova Mogila barrow (G 3) (after Simonenko 2008); 3. Sladkovka, 1977 (T 6 G 1) (after Maksimenko 1998). 


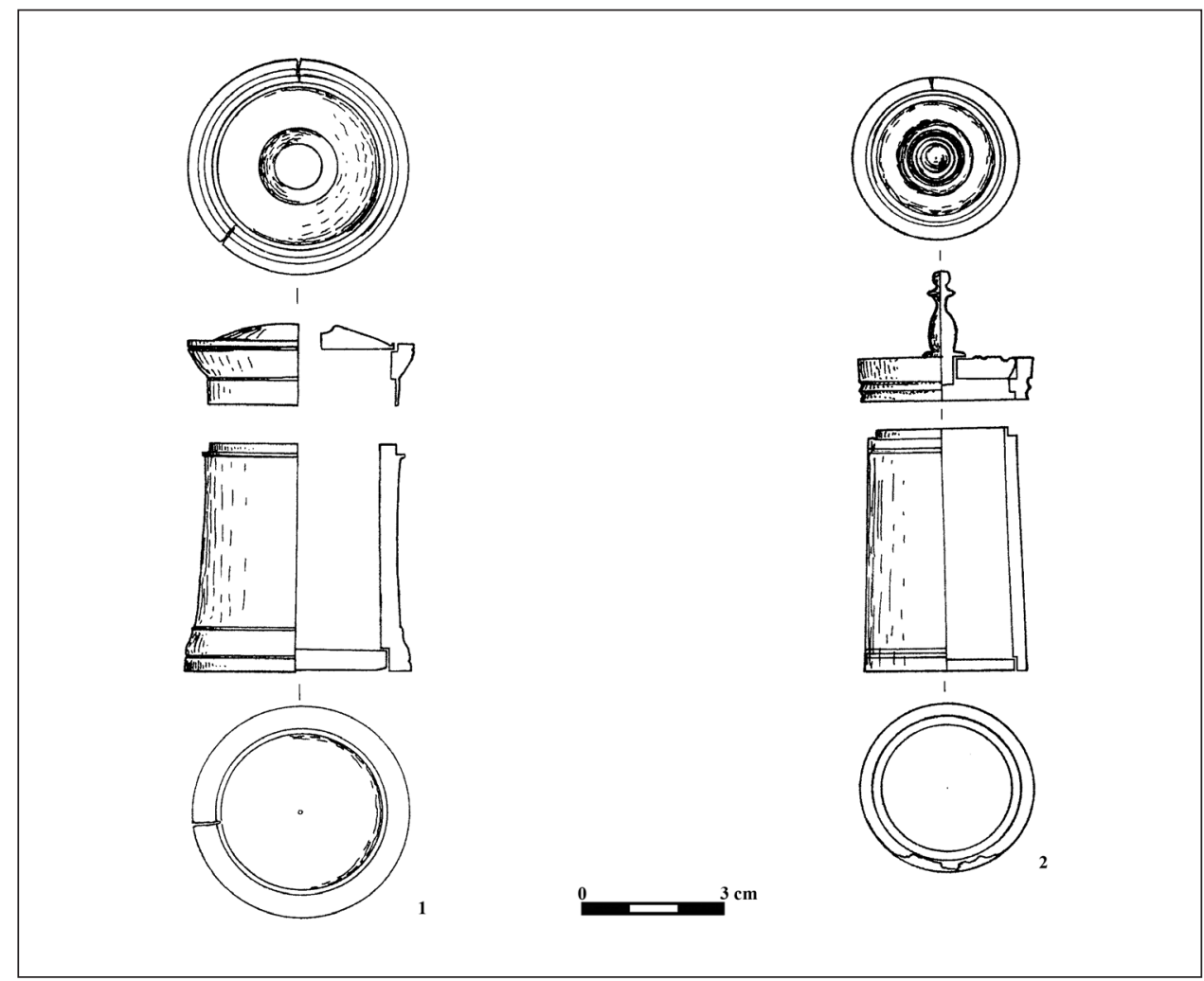

Fig. 3. Bone pyxides. 1. Novo-Podkryazh ( 13 G 1); 2. Ust'-Kamenka ( 45 G 1) (after Simonenko 2008).

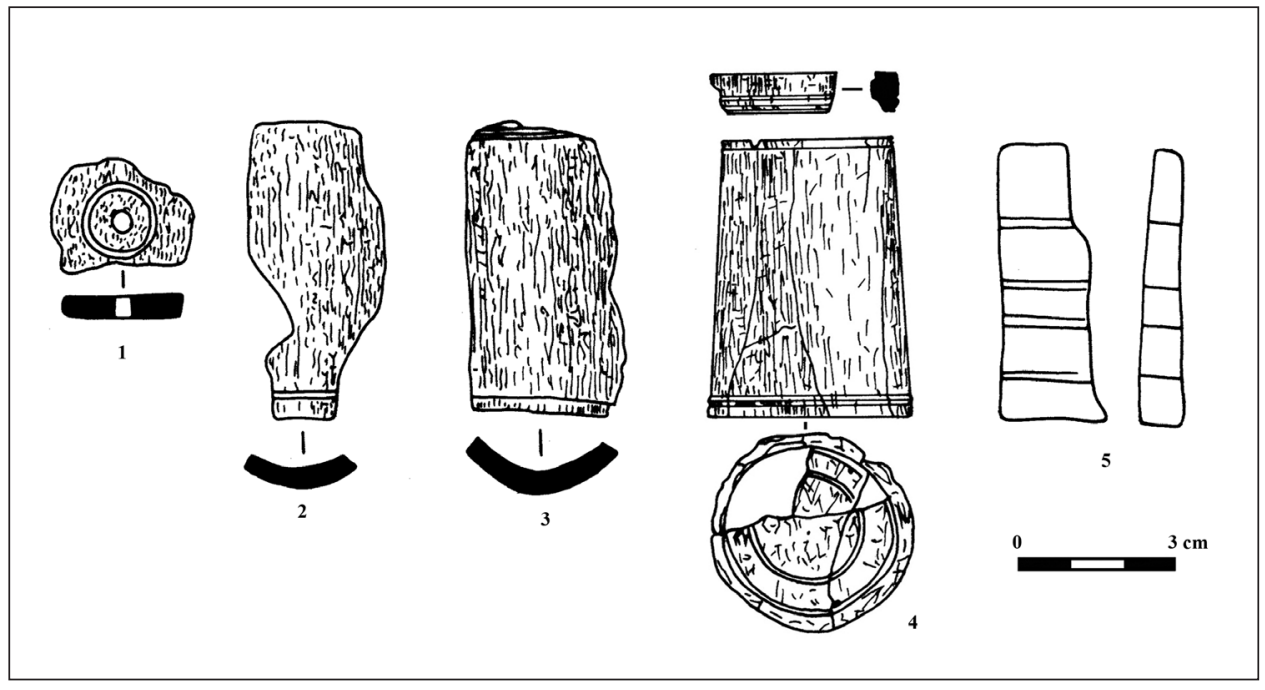

Fig. 4. 1-3. Bădragii Vechi (T 20 M 1); 4. Bădragii Vechi (T 27 G 1); 5. Dumeni (T 9 G 13) (after Bârcă 2006). 
G 13 from Dumeni (Fig. 4/5) (Grosu 1988, 84, Fig. 3/7; Grosu 1990, 58; Bârcă 2006, 161, 309, Fig. 51/1).

Such bone pieces are also present in a series of Sarmatian graves from the north-east of the Black Sea, the Don-Volga interfluve and the territories east of Volga (Cf. Fig. 9).

In the Kuban region (north-east of the Black Sea) bone pyxides, either complete or parts of them, were discovered in the secondary grave from the "Ostryj" barrow at Yaroslavskaya ${ }^{12}$ (Fig. 6/1) (Marčenko and Limberis 2008, 309, 335, cat. no. 2.6, Pl. 2/2), in the graves from T $44^{13}$ (Fig. 5/1) (Gushchina and Zasetskaya 1994, 33, 49, cat. no. 127, Pl. 13/127; Marčenko and Limberis 2008, 309, 347, cat. no. 40.2, Pl. 69/8) and T $45^{14}$ (Fig. 5/2) (Gushchina and Zasetskaya 1994, 33, 49, cat. no. 132, Pl. 13/132) between the places of Kazanskaya and Tiflisskaya (Tbilisskaya), the graves in T $18^{15}$ (Fig. 5/3) (Gushchina and Zasetskaya 1994, 33, 60, cat. no. 300, Pl. 32/300; Marčenko and Limberis 2008, 309, 350, cat. no. 51.3, Pl. 78/2) and T $20^{16}$ (Fig. 5/4) (Gushchina and Zasetskaya 1994, 33, 62, cat. no. 322, Pl. 34/322; Marčenko and Limberis 2008, 309, 350, cat. no. 52.3, Pl. 81/3) from Tiflisskaya (Tbilisskaya), to which adds the specimen from the barrow grave at Kunchukokhabl ${ }^{17}$ (Fig. 6/2) (Marčenko and Limberis 2008, 309, 356, cat. no. 74.4, Pl. 110/1).

In the Don-Volga interfluve such fragmentary pieces were discovered in the rich barrow grave (T 1 G 1) at "Dachi" (Fig. 6/3) (Bespalyj 1992, 177, Fig. 1/6), T 1 G 1 at Vysochino, 1978 (Maksimenko 1998, 132), T 2 G 1 at Novoaleksandrovka, 1977 (Maksimenko 1998, 132) (left of the Danube mouths) and T 44 G 1 in the Krivoj Liman cemetery, left of the Lower Don, 1980 (Fig. 6/4) (Maksimenko 1998, 132, Fig. 16/6, 55/12; Bespalyj and Luk'yashko 2018, 9, 11, 12, Fig. 373). To these adds the specimen from the main grave of a Sarmatian barrow from Sadovoe ${ }^{18}$ (Fig. 7) (Firsov 1998, 129, 133-134, Fig. 3), west the Lower Volga.

In the territories east of Volga, a bone pyxis comes from grave $\mathrm{T} 6$ in the Kurpe Baj cemetery (Western Kazakhstan) ${ }^{19}$ (Fig. 8) (cf. Senigova 1956, 144, 148, Pl. IV/1; Moshkova 1989, 188).

\footnotetext{
${ }^{12}$ Height $-3.8 \mathrm{~cm}$; diameter $-3.7 \mathrm{~cm}$.

${ }^{13}$ Height $-4.5 \mathrm{~cm}$; diameter $-3 \mathrm{~cm}$.

${ }^{14}$ Surviving base diameter $-2.9 \mathrm{~cm}$.

${ }^{15}$ Height $-5.5 \mathrm{~cm}$; diameter $-3 \mathrm{~cm}$.

${ }^{16}$ Height $-5.3 \mathrm{~cm}$; diameter $-3.2 \mathrm{~cm}$.

${ }^{17}$ Height - $5 \mathrm{~cm}$; mouth diameter $-3 \mathrm{~cm}$; base diameter $-4 \mathrm{~cm}$.

${ }^{18}$ Body height $-3.1 \mathrm{~cm}$; outer mouth diameter $-2.1 \mathrm{~cm}$; outer lid diameter- $3.1 \mathrm{~cm}$; base diameter $2.6 \mathrm{~cm}$.

${ }^{19}$ Height - $4 \mathrm{~cm}$; mouth diameter $-3.5 \mathrm{~cm}$; base diameter $-4 \mathrm{~cm}$.
} 


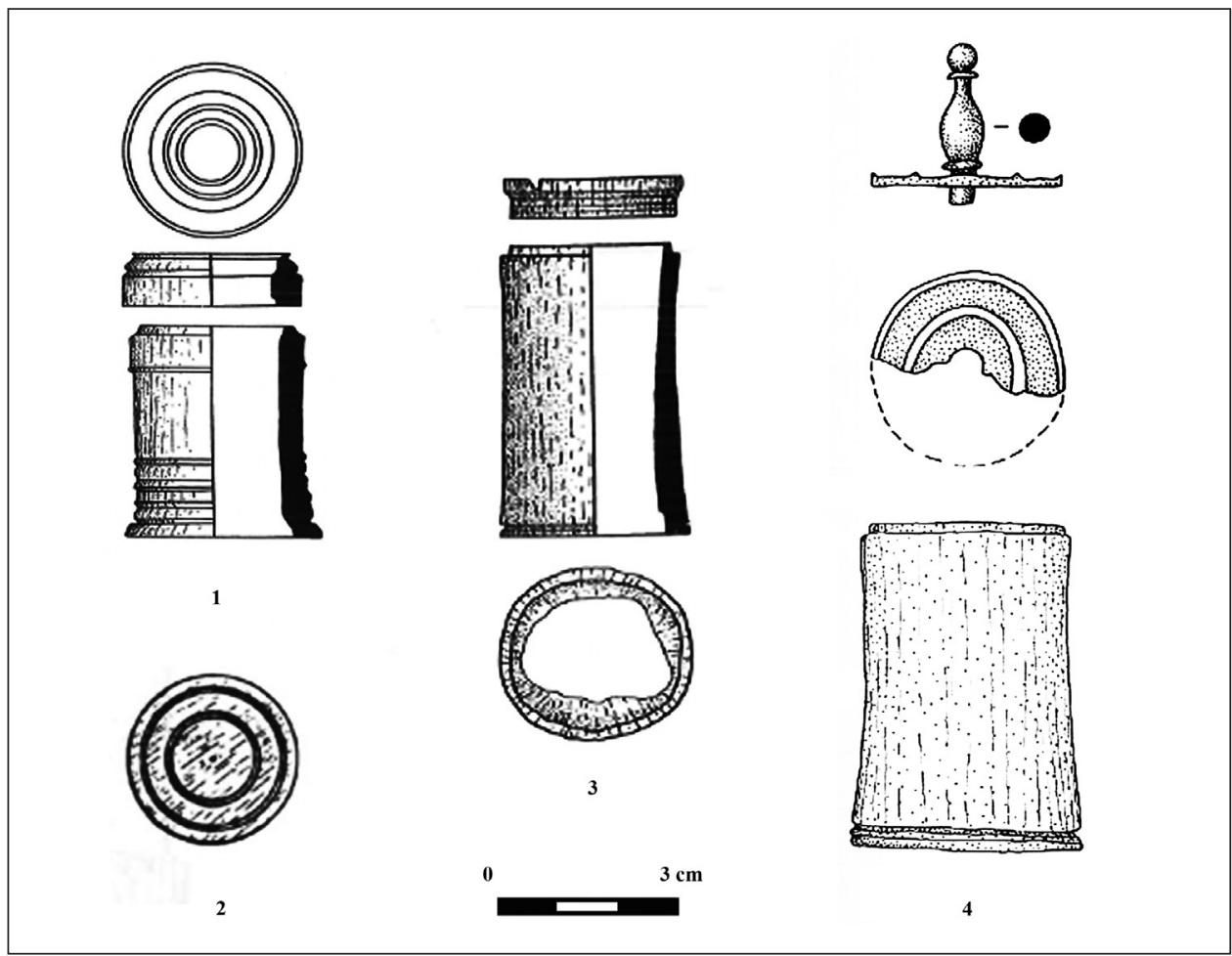

Fig. 5. Bone pyxides. 1. Kazanskaya/Tiflisskaya (T 44); 2. Kazanskaya/Tiflisskaya (T 45); 3.

Tiflisskaya (T 18); 4. Tiflisskaya (T 20) (after Marčenko and Limberis 2008 (1, 3-4); Gushchina and Zasetskaya 1994 (2)).

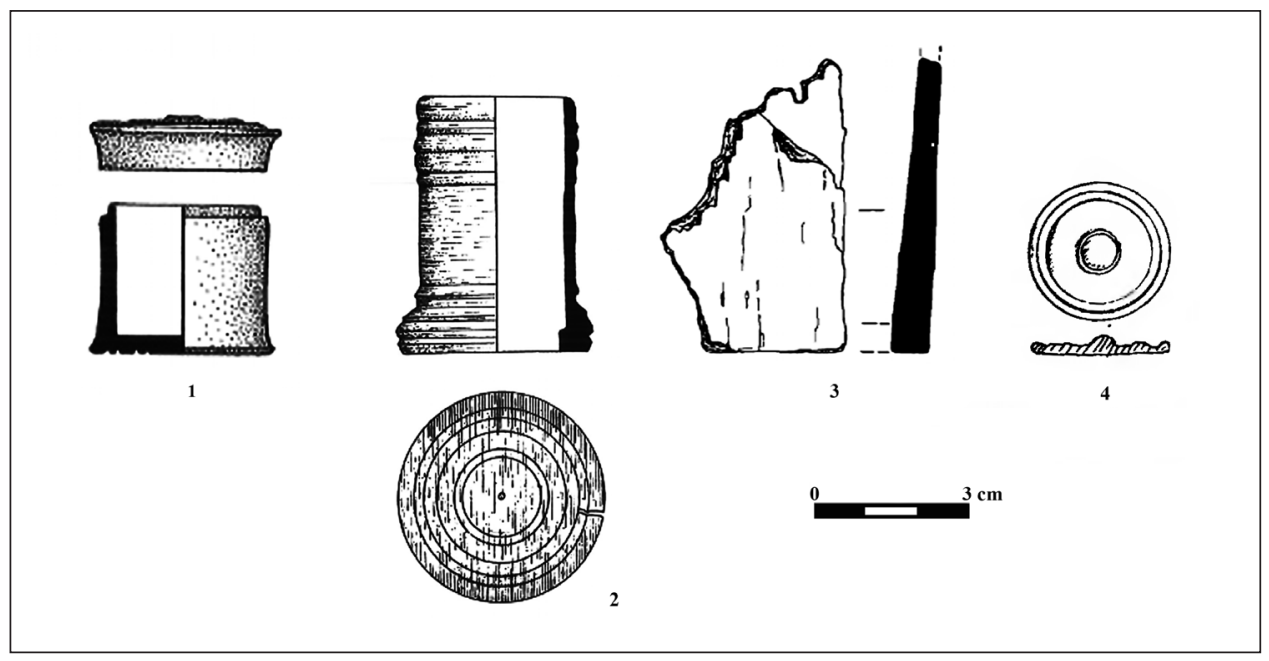

Fig. 6. Bone pyxides. 1. Yaroslavskaya ("Ostryj" barrow); 2. Kunchukokhabl' (after Marčenko/ Limberis 2008); 3. "Dachi" (T 1 G 1) (after Bespalyj 1992); 4. Krivoy Liman (T 44 G 1) (after Maksimenko 1998). 
In the Sarmatian environment of the Great Hungarian Plain the pyxides discovered within graves are mainly of metal (Cf. Párducz 1941, Pl. XXII/4; Párducz 1950, 9, 24, 26, Pl. VII/5a-b, VIII/7, LXXII/9, LXXIV/3, 5; Párducz 1950a, 69, 70-71, Pl. XIV/2/1a-e; Vaday 1980, 57, Pl. 19/2; Vaday 1989, 124, 259, cat. no. $214 / 8$, Pl. 74/11, 281, cat. no. 396/3, Pl. 153/8; Vaday and Szőke 1983,113; Bozsik 2003, 102, Fig. 7/6, 8/6; Bârcă 2014, 136-138; Bârcă 2017), bone artefacts being currently unknown.

From the point of view of the geographical location, in the territories east of Volga there is only one piece, it being in fact the most eastern find. In the Don-Volga interfluve, these artifacts are represented by five finds. Amongst, three are from the left of the Don mouths, one from around the Lower Don and the fifth from a place located half the way between the Volga and the Lower Don. Other six pyxides come from the north-east of the Black Sea (Kuban region) (Fig. 9).

In the case of the finds above, the majority come mainly from territories closer to the Bosporan Kingdom.

In the north-Pontic Sarmatian environment between the Don and the Prut, such artifacts are represented by 13 finds. Amongst, six come from the area between the Don and the Dnieper, three from the Dnieper-Bug interfluve, a specimen comes from the right of the Lower Bug, and other three from the area between the Dniester and the Prut (Cf. Fig. 9).

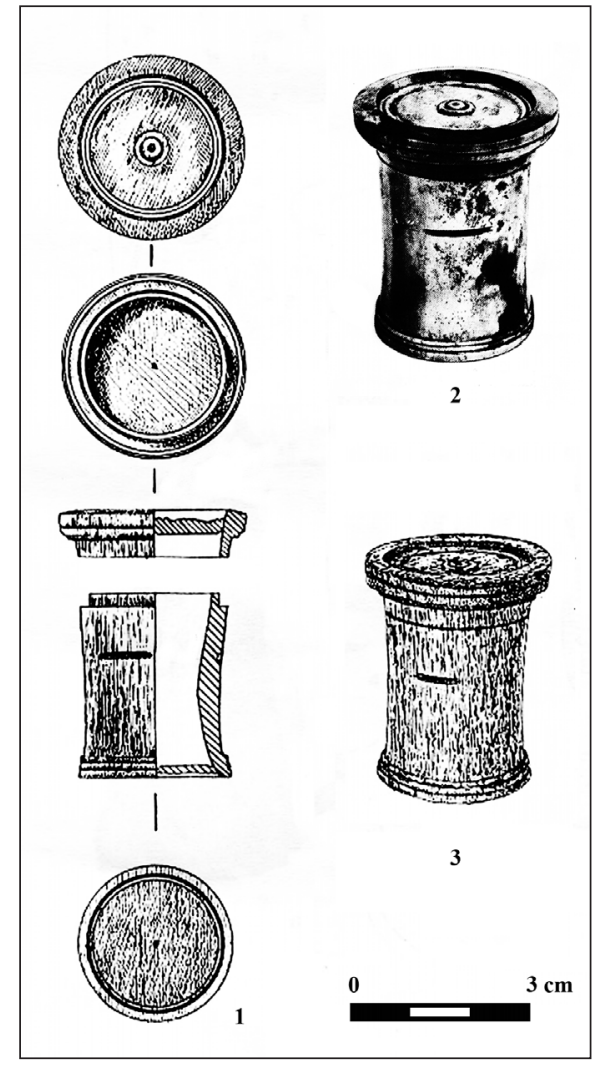

Fig. 7. Bone pyxis in the Sadovoe barrow (after Firsov 1998).

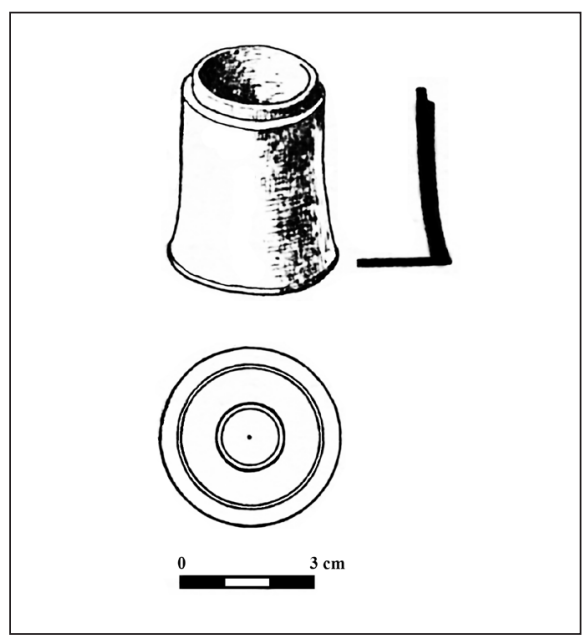

Fig. 8. Bone pyxis in barrow 6 from the Kurpe Baj cemetery (after Senigova 1956). 


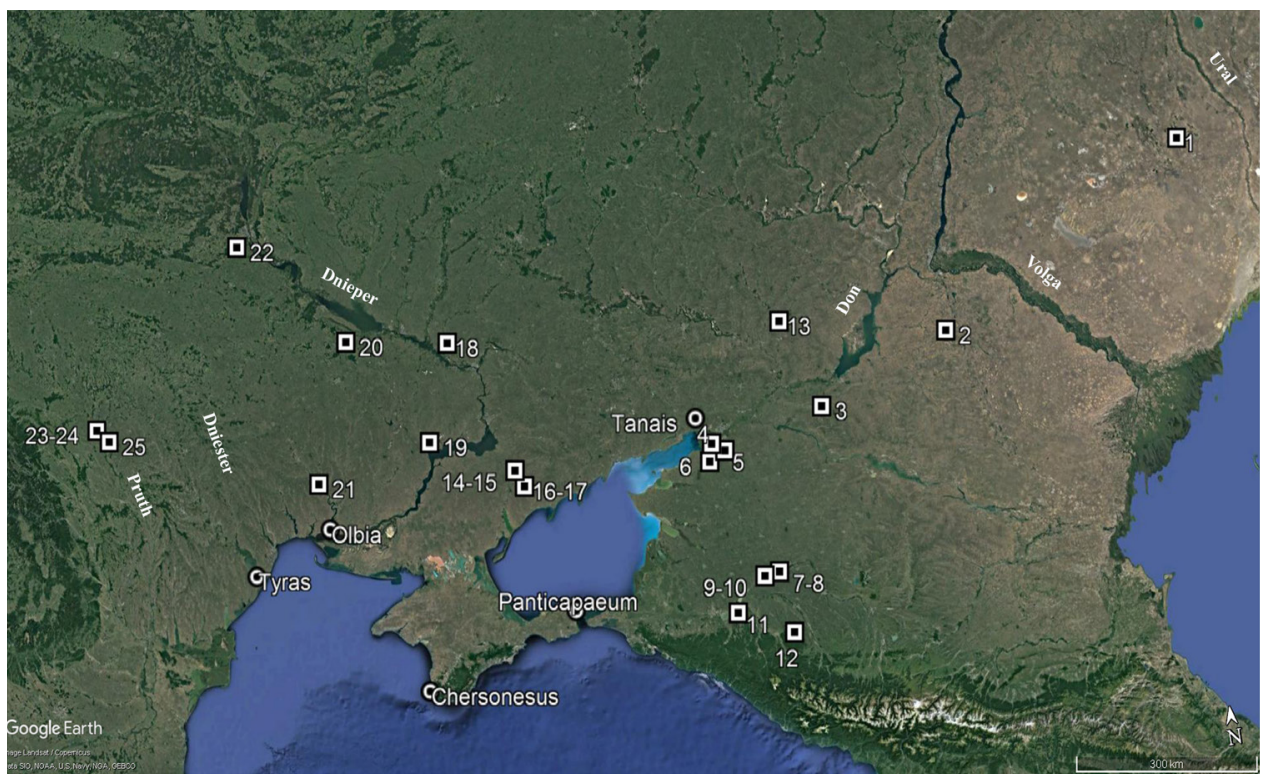

Fig. 9. Map of bone pyxides distribution in the Sarmatian environment from the territories between the Prut and Ural Negre: 1. Kurpe Baj; 2. Sadovoe; 3. Krivoj Liman (T 44 G 1); 4. "Dachi” (T 1 G 1); 5. Novoaleksandrovka (T 2 G 1); 6. Vysochino (T 1 G 1); 7. Kazanskaya / Tiflisskaya (T 44); 8. Kazanskaya / Tiflisskaya (T 45); 9. Tiflisskaya (T 18); 10. Tiflisskaya (T 20); 11. Kunchukokhabl'; 12. Yaroslavskaya ("Ostryj" barrow); 13. Sladkovka, 1977 (T 6 G 1); 14. Novofilippovka (T 2 G 1), 15. Novofilippovka (T $2 \mathrm{G}$ 1, eastern grave group), 16. Akkermen' II (T 18, western grave group), 17. Akkermen' II (T IV, eastern grave group), 18. Novo-Podkryazh ( $T 13$ G 1), 19. Ust'-Kamenka ( $T$ 45 G 1), 20. Tsvetna, 21. Kovalevka, tumulus Sokolova Mogila (G 3), 22. Krasnopolka (T 424 G 2), 23. Bădragii Vechi (T 20 G 1), 24. Bădragii Vechi (T 27 G 1), 25. Dumeni (T 9 G 13).

All bone specimens from within the graves between the Don and the Prut, but also in the Sarmatian environment of the territories east of the Don and Volga, as well as from the north-east of the Black Sea, are characterised by a series of general typological features. Their body is cylindrical or cylindrical with slightly concave walls, while some of the specimens have the body slightly narrowed in the upper part. Their diameter is not very large, which is explained by the specificity of the material they are made of. A part of the pyxides are decorated in the lower body half with incised lines. The base of all pyxides is made of another disc-shaped bone piece, occasionally decorated with incised concentric circles, set on their cylindrical body. The lid is most often profiled, some specimens having set an elongated profiled knob in the lid's central part ${ }^{20}$. Most lids are made of a circle-shaped body in which the disc piece is set, yet there are also specimens made of a single bone piece. The lid disc is either bulg-

${ }^{20}$ Their shape is similar to that of the chess pown. 
ing or decorated with sunken concentric circles, forming a well marked surface. Among the bone pyxides from the north and north-Pontic Sarmatian environment there are no specimens with depictions figured in relief on their body, like those in the Roman environment ${ }^{21}$.

All bone pyxides from the Sarmatian graves have numerous parallels among the finds from various cultural environments of the first two centuries $\mathrm{AD}$, but especially in that Roman provincial. The pieces in the Sarmatian environment have parallels also among the wood pyxides from the north-Pontic space of the first centuries AD (Sokol'skij 1971, 205, Pl. XXIX/6, 8, 10, 11, 15, XXX/3, 6, 8, XXXI/7-11).

The pyxides in the Sarmatian environment of the territories between the Don and Prut were discovered beside various classes of artifacts. They, together with other elements, allow a more accurate chronological framing of both graves and period of use.

The grave at Novofilippovka ( 2 G 1), for which information regarding the pit shape and the position of the deceased is missing, contained among the grave goods scarabs of Egyptian faience, grape-shaped pendants, amphora-shaped pendants and an altar-shaped amulet, all of Egyptian faience. To these adds a returned foot brooch, three pottery wares, of which worthy of note is a wheel-thrown cup with everted rim and spout (Simonenko 2008, 80, Pl. 136, Simonenko 2011, 174, cat. no. 11, Fig. 24, 69/16).

In A. K. Ambroz's classification, the brooch of Novofilippovka belongs to the second variation of series I in group 15 of brooches characterised by not very curved, downward bow, and foot slightly widened by the extremity compared to the rest of the body (Ambroz 1966, 49, Pl. 9/7). The same author includes in this series both outer chord brooches and those with inner chord, of which it was argued that only part of the early specimens had inner chord (Ambroz 1966, 48 sqq.). The brooches in the second variation were dated by A. K. Ambroz to the 1st century AD, mainly the second half, without yet excluding the possibility of their use by early 2nd century AD (Ambroz 1966, 49).

The large number of such brooches made of a single metal piece with inner chord discovered in the last four decades, allowed V. V. Kropotov (Kropotov 2010, 129-150) to frame all specimens in series II of brooches with returned foot wound onto the bow from the fourth group. Within the series, they were divided, based on certain peculiarities, into four variations. The brooch from Novofilippovka belongs to shape 1 of the second variation of series II (Krop-

${ }^{21}$ For such pyxides see references in works quoted in note 6. 
otov 2010, 131, Fig. 40/2, 5, 11). Finds of such brooches mainly cluster in the Lower Dnieper river basin and Crimea, yet they are also sporadically found in the Kuban region, North Caucasus and the north-west Pontic territories. Chronologically, brooches in this variation are dated to the second half of the 1st c. - early 2nd c. AD (Kropotov 2010, 131), as in fact confirmed by the artifacts they were identified with within the features.

The second grave from Novofilippovka ( $\mathrm{T} 2 \mathrm{G}$ 1, eastern group of graves) is a main burial within a Sarmatian barrow. The gravepit is rectangular $(2.2 \mathrm{x} 1$ $\mathrm{m})$, had the dead placed head towards the SW. The grave was looted. Beside the pyxis, among the surviving grave goods count a wheel thrown cup, a fragment of a massive bronze piece, a quiver with three-winged iron arrowheads, with socket, bronze rivets and one terra sigillata (Vyaz'mitina et al. 1960, 44-45, Fig. 27; Simonenko 2008, 80, Pl. 137/1-7; Simonenko 2011, 174, cat. no. 12) aryballos, indicative of a dating to the second half of the 1 st - early 2 nd c. AD.

The grave in T 18 from Akkermen' II is a main burial, in a rectangular pit $(1.8 \times 0.6 \mathrm{~m})$, with the dead head towards SW. It was looted. The grave goods also contained a bracelet, five clasps in the shape of links and one earring, all of bronze, to which also adds a glass bead and a handmade jar (Vyaz'mitina et al. 1960, 78, Fig. 64; Simonenko 2008, 80-81, Pl. 139/2a-e; Simonenko 2011, 176, cat. no. 17).

The grave in T IV at Akkermen' II (eastern group of graves) is a main burial, in a square pit (Vyaz'mitina et al. 1960, 84-85, Fig. 68; Simonenko 2008, 81, Pl. 141/1a-f; Simonenko 2011, 176-177, cat. no. 19). Alike the preceding, it was also looted. Beside the pyxis, among the grave goods were recovered a wheelthrown jug with strongly everted rim shaped as a funnel, short narrow neck, bulging body and ringfoot, a small wheel-thrown jar, handmade pottery fragments, a tazza type vessel with inverted rim, a bronze buckle with ring-shape prong and a bronze brooch. The latter has bilateral spring made of four coils, outer chord, curved widened bow in the form of a rhomboid plate, solid catchplate, rectangular and foot extremity raised above and twisted in the form of a loop/coil. The bow is decorated with incised oblique lines.

In A. K. Ambroz's typology, such brooches belong to variation three of group 13 (Ambroz 1966, 45, Pl. 5/15-16). The same author maintains they were used extensively over the 1 st c. AD, partially found also by early 2 nd c. AD (Ambroz 1966, 45). In V. V. Kropotov's recent classification, such brooches are part of series I, form 3 of group 8 (Kropotov 2010, 185, Fig. 55/11-14, 16, $21,23)$. Chronologically, the six forms of this series are often found together in both features of the second half of the 1st - early $2 \mathrm{nd} \mathrm{c.} \mathrm{AD} \mathrm{and} \mathrm{in} \mathrm{some} \mathrm{later}$ (Kropotov 2010, 185). This indicates their use for a long time. The finds of such 
brooches cluster mainly in the Lower Don area, Crimea, Kuban region and the territory north the Caucasus, but also sporadically in the territories from the north and north-west of the Black Sea (Kropotov 2010, 185, 186-201, Fig. 56).

Based on the dating of the artifacts from the grave in T IV, yet also the chronological framing of the other graves from Akkermen' II, it may be argued they date sometime to the second half of the 1st c. - early 2 nd c. AD.

The pyxis from Novo-Podkryazh (T 13 G 1) counts among the grave goods of a main catacomb grave, with the deceased extended, head to the NW. The goods also included a wheel-thrown jar and cup, a whetstone, a mirror with round and flat disc, amethyst and carnelian beads, but also one amber and crystal bead each (Kostenko 1977, 124; Simonenko 2008, 60, Pl. 26, 27/1a-c; Simonenko 2011, 186, cat. no. 48).

Mirrors of the type at Novo-Podkryazh are the simplest type of such toiletries from the Sarmatian world, being used as early as the Early Sarmatian period (Cf. Khazanov 1963, 62; Maksimenko 1983, 96-97, Fig. 16-17, 19; Skripkin 1990, 150; Skripkin and Klepikov 2004, 99, Fig. 4/31-35; Marchenko 1996, 19-20; Bârcă 2006a, 93-95; Bârcă and Symonenko 2009, 74-75; Simonenko 1993, 28; Simonenko 2004, 139). They were massively used by the Sarmatians in the 1st c. BC - 1st c. AD (Khazanov 1963, 64), particularly in the latter (Skripkin 1990, 153; see for finds of mirrors of the type to the 1st c. AD in Abramova 1971, 121132; Grosu 1990; Simonenko and Lobaj 1991, 57; Kostenko 1993, 106, 113; Simonenko 1993, 85; Marchenko 1996, 19-20; Bârcă 2006, 148-150; Bârcă 2006a, 93-95; Bârcă and Symonenko 2009, 74-75, 171-172; Glukhov 2003; Simonenko $2004,139,144)$. Once with the end of the 1 st c. AD, such mirrors ceased to exist in the Sarmatian world east of the Don, while by early 2 nd c. AD only singular specimens may be found (Khazanov 1963, 64; Skripkin 1990, 153, Fig. 44. A. A. Glukhov believes that in the Don-Volga interfluve, the upper limit of the use of round disc mirrors may be placed most likely by mid 1 st c. AD, without yet excluding some specimens being fashionable also in the second half (Glukhov 2003, 91). In the north-Pontic region east of the Don, mirrors of the type are frequent within 1st c. AD-graves, especially the second half. In the same area, simple disc mirrors are rare also in a series of graves from early/first half of the 2 nd c. AD. Mirrors with round flat disc are present also in other cultural environments (Cf. Bârcă 2006, 149 with bibliography), the Great Hungarian Plain Sarmatian milieu included (Istvánovits and Kulcsár 1993, 9-58; Bârcă 2016, 55-61).

The grave at Ust'-Kamenka ( $45 \mathrm{G} 1)$ is a main burial in a square funerary pit with the deceased (woman) extended, head to the NW. Its grave goods include, beside the pyxis, a wheel-thrown bowl, reddish, a glass unguentarium, a bronze bowl, a bronze brooch, a pendant and bronze clasps, two wheel-thrown 
censers and one vessel, a wheel-thrown jar, an iron knife, two spindle weights and many glass, crystal, carnelian and onyx beads (Kostenko 1993, 48-50, Fig. 16, 17/1-20; Simonenko 2008, 64, Pl 48/2a-e, 49-50; Simonenko 2011, 190-191, cat. no. 59).

The brooch has bilateral spring, formed of four coils and outer chord, bandshaped flattened bow and trapezoid catchplate. The bow is decorated by incisions and has a knob by the foot end.

In A. K. Ambroz's typology, the brooch at Ust'-Kamenka may be framed to the first three brooch variants with flattened bow and trapezoid catchplate with a more or less marked knob by the end (group 12) (Ambroz 1966, 43, Pl. 5/2-9). In V. V. Kropotov's recent work, such brooches belong to variation 2 in group 9 (Kropotov 2010, 212, Fig. 61-62), though some features ascribe it also to the first variation.

A. K. Ambroz dated the brooches in the first variation to the 1st c. AD, while those in variation three to the end of the 1 st - first half of the 2 nd c. AD (Ambroz 1966, 43). The first two variations of the specimens from Crimea are dated to the last quarter of the 1 st $\mathrm{c}$. $\mathrm{AD}$, while the emergence of the brooches in variation three is placed by the eve between the 1 st $-2 \mathrm{nd}$ c. $\mathrm{AD}$, with the note of use of some specimens until mid-third quarter of the 2nd c. AD (Puzdrovskij $2007,181,185,188)$. Subsequent to the analysis of all these brooches from the north-Pontic area, V. V. Kropotov concluded that the specimens in the first variation date to the second half of the 1st - early 2 nd c. AD, while those in the second over the 2nd c. AD (Kropotov 2010, 213). The finds of such brooches cluster mainly in the lower Don area, Crimea and the Kuban region, but also sporadically in the territories from the north and north-west of the Black Sea (Kropotov 2010, Fig. 60, 62).

Another very good dating element is the glass unguentarium of type Isings 6 . Such unguentaria were dated by C. Isings to the 1st c. AD (Isings 1957, 22-23). N. Z. Kunina and N. P. Sorokina ascribe such glass vessels to type II, being dated to the 1st - early 2nd c. AD (Kunina and Sorokina, 1972, 169-171, Fig. 11). In the Sarmatian and Meotian environment from the Kuban region, such pieces come from second half of the 1 st - early $2 \mathrm{nd}$ c. AD graves (Marčenko and Limberis 2008, 303, map, 9, cat. no. 51, 2, 73, 4, 127, 1, 141, 1, 157, 1, 172, 1, 198, 6-7).

The find of two censers within the same grave, occasionally one on top of the other, is a chronological and cultural mark of the Middle Sarmatian period (Skripkin 1990, 99). In the Sarmatian graves from the north and north-west Pontic area, this innovative custom emerges by mid 1 st c. AD and is found mainly in a series of graves and cemeteries from the second half of the 1st - early/first half of the 2nd c. AD (Cf. Bârcă 2006, 77; Bârcă 2015, 53; Bârcă and Symonenko 
2009, 117-118). This custom as well as some censer types were carried to the north and north-Pontic area by the new Sarmatian tribes arriving from the east. In fact, it is not fortuitous that the finds from the north and north-west of the Black Sea come mainly from most definite eastern feature graves.

On the basis of the dating of all artifacts from the grave in $T 45$, it may be argued it dates sometime to the end of the 1st c. - early 2 nd c. AD.

The pyxis from Tsvetna was discovered together with a bronze jar (Oinochoe) with trilobate rim of type Eggers 124, a type Eggers 137 bronze casserole, a silver jar, not very vertical with ringfoot, a bronze cauldron, a golden bracelet with hexagonal section, a golden buckle, a cauldron-shaped pendant and several types of golden dress appliques, belt fittings, a fine red fabric wheel-thrown cup, fragments of a dark grey cup and from an amphora handle. There add also sword fragments and several three-winged iron arrowheads with socket etc. (Simonenko 2008, 69-70, Pl. 77-81; Simonenko 2011, 203-206, cat. no. 90, Fig. 7/1-2, 18/6-7, 28, 40; Mordvintseva and Trejster 2007, II, 136, no. B46). Based on each of the piece dating it may concluded that the entire feature dates to the second half - last 1st c. AD (Simonenko 2008, 15; Simonenko 2011, 40; V. Mordvintseva and M. Trejster date the feature to the mid-third quarter of the 1st c. AD (Mordvintseva and Trejster 2007, II, 136).

The grave from the Sokolova Mogila barrow is a secondary burial in a Bronze-date barrow with rectangular funerary pit. The deceased (woman) lay extended on the back, head to WSW. Its rich furnishing included an oinochoe, skyphos and silver spoon, a bronze situla, one ring, earrings, bracelets, collars, brooches and golden dress appliques, bronze rings, two fans (flabella) with silver and bone handles, a bronze mirror with handle in the shape of a male's face with eastern facial features, sitting with legs crossed, a bone comb, to which add many beads of semiprecious and glass stones, cauldron-shaped pendants, a marble vessel, one of alabaster, a wheel thrown jug and dish, one censer, bowl and box with wooden lid (Kovpanenko 1986, 9-110, Fig. 23-118; Simonenko 2008, 74-75, Pl. 103-111; Simonenko 2011, 220-225, cat. no. 110).

Most pieces date to the 1 st c. AD, yet there are artifacts with a somewhat broader chronological framing. Based on the dating of all these artifacts we believe that in G 3 from the Sokolova Mogila barrow, which included also a pyxis, is dated, as previously mentioned, to the second half of the 1st c. AD (possibly the third quarter or last third) (See also Bârcă 2011, 10; Bârcă 2015, 41; Simonenko 2011, 43-44) and not the first half as dated by G. T. Kovpanenko (Kovpanenko 1986, 127).

The grave at Krasnopolka ( $\mathrm{T} 424 \mathrm{G} 2$ ) is a secondary burial with the deceased (woman) placed with head to the north in a coffin made of a hollowed 
tree trunk (?). Beside the pyxis, the grave goods also included handmade and wheel-thrown pottery, glass, quartz and carnelian beads, a golden link with loop, bronze links, spindle weights, a rectangular mirror, yet also a Eggers 140 (Simonenko 2008, 68, cat. no. 81, Pl. 165; Simonenko 2011, 194, cat. no. 68; Bârcă 2014a, 53-54) bronze casserole. Subsequent to the study of all casseroles bearing the artisan's stamp as well as the contexts of their find, it was reached the conclusion that the production start of this casserole type must be placed sometime in $\mathrm{AD} \mathrm{5/10,} \mathrm{while} \mathrm{their} \mathrm{cease} \mathrm{sometime} \mathrm{around} \mathrm{AD} 30 / 35$, no later than the end of Tiberius's reign (Petrovszky 1993, 52-54). Nonetheless, a significant part of these casseroles were discovered on the entire duration of the 1st c. AD and early following century, as the case of the Sarmatian graves dated to the end of the 1st c. AD - early 2 nd c. AD (Cf. Kropotkin 1970, 95, no. 822; Medvedev and Yefimov 1986, 84; Grosu 1990, 61; Simonenko 2008, 17, 71; Bârcă 2001, 338; Bârcă 2006, 171; Bârcă 2009, 101-103; Bârcă and Symonenko 2009, 188; Simonenko 2011, 49-52).

Rectangular mirrors like the one in respective grave were very popular and widely spread in most part of the Roman provinces of the 1st c. AD. Their majority come from 1st c. AD contexts and complexes, yet there are also cases when they remained fashionable for a longer time span (For rectangular mirrors in the Roman environment see Lloyd-Morgan 1977, 231-252; Lloyd-Morgan 1980, 97, 104; Lloyd-Morgan 1981, 145, 155; Lloyd-Morgan 1981a, 3-20). There is no information regarding the production of rectangular mirrors over the $2 \mathrm{nd}$ c. AD (Lloyd-Morgan 1980, 97; Lloyd-Morgan 1981a, 3). In the north-Pontic Sarmatian environment, rectangular mirrors are part of graves dated mainly to the second half of the 1st c. - first decades of the 2 nd c. AD (for the rectangular mirrors in the Greek and Sarmatian environment from the north-Pontic space see Bârcă 2014a, 49-63 with complete bibliography, while for those in the Sarmatian environment of the Great Hungarian Plain (Istvánovits and Kulcsár 1993, 14).

The dating of the Krasnopolka grave may be placed most likely sometime in the second half of the 1st c. - early 2 nd c. AD.

The pyxides from Bădragii Vechi are part of the furnishing of two graves ( $\mathrm{T}$ 20 G 1, T 27 G 1), which are secondary burials in Bronze Age barrows. The funerary pit of the grave in $\mathrm{T} 20$ was trapezoid, while that of the grave in $\mathrm{T} 27$ could not delimited. The dead in T $20 \mathrm{G} 1$ was placed head to NNW, while that in T 27 G 1 was extended with head to NE (Cf. Bârcă 2006, 277, 283, Fig. 7/1, 17/1).

The grave goods of T $20 \mathrm{G} 1$ included beside the fragmentary pyxis, a glass fragmentary bead, a bronze mirror with round, flat disc (while metal), fragments of an iron piece and a wheel-thrown cup (Bârcă 2006, 277-278, Fig. 7/2$6)$. The latter is identical with the specimens of type Knipovič 4(M), dated to 
the first two thirds of the 1st c. AD (Knipovich 1952, 296-297, Fig. 1/4), with those of Robinson M 33 type, dated to the second half of the 1st c. - first half of the 2nd c. AD (Robinson 1959, 87, Pl. 18, 62) and those belonging to form Hayes 70 (Hayes 1985, 63, Pl. XIV/19). It is very similar also to the Robinson G 28, G 70-71 (Robinson 1959, 25, Pl. 4, 62) type cups, dated to the first half of the 1st c. AD and those of Robinson $\mathrm{H} 7$ type, dated to the first half of the 2nd c. AD (Robinson 1959, 47, Pl. 8, 68). Recipients of the type are part of the class of terra sigillata orientales $B$, known in the specialty literature as "Samian" (see in detail Hayes 1985, 49-70).

A somewhat richer furnishing had the grave in $\mathrm{T} 27$, comprising a silver fragmentary earring, a bronze brooch, several amber, agate, carnelian and glass beads, a bronze casserole, the handle of a bronze vessel, a mirror and two bronze plates, an iron knife, a bone cylindrical fragmentary piece, a spindle weight, a handmade censer, a jar and a wheel-thrown cup (Cf. Bârcă 2006, 283285, Fig. 17-19).

The brooch is strongly profiled with inner chord and bilateral spring formed of 12 coils and chord inserted under the bow. The bow was decorated with two knobs: one towards the bow head and the other divides the bow from foot. The latter has a small knob by the end, while the catchplate is trapezoid. The brooch is made of two metal parts.

Regarding the peculiar strongly profiled brooch making of two metal pieces (brooch body, on one hand and the spring with pin on the other) it occurred towards the end of the 1st c. AD and generalizes in the first decades of the 2 nd c. AD (Rustoiu, 1997, 54). Strongly profiled brooches made of two parts are documented by the end of the 1st - early 2nd c. AD also in pre-Roman Dacia, where they are Roman imports (Rustoiu 1997, 54).

The brooch from Bădragii Vechi has no identical parallel presently. However, since it has inner chord, we may assume it may be a product of a workshop from the Barbaricum, possibly the eastern Getae-Dacian environment, where workshops making them also functioned (Rustoiu 1997, 20-21).

The casserole in this grave belongs to type Eggers 142 and preserves on the exterior handle part the stamp LAN II/I. Such casseroles were discovered in various cultural environments throughout the Europe of the early Roman imperial period (Cf. Bârcă 2009, 103-104, with bibliography).

Based on the analysis of all casseroles bearing the artisan's stamp as well as the find contexts, R. Petrovszky concluded that their production started sometime in AD 35-40 and their cease in the 90's of the 1st c. AD (Petrovszky 1993, 71). Based on the large number of such casseroles with the artisan's stamp on the handle, it was established they were mainly made in the workshops of the Ansii and 
Cipii in Capua (Campania) (Lund Hansen, 1987, 48-49; Petrovszky 1993, 69-71), but also occasionally in Gaul (Petrovszky 1993, 69, 71). The stamp on the specimen from Bădragii Vechi belongs to artisan Lucius Ansius Epaphroditus making vessels in Capua between AD 50/55 and 85 (Petrovszky 1993, 143, 144, 207).

Alike the Eggers 140 type casseroles, those of type 142 were used in some cases for a long period of time, being also found in the 2 nd c. AD.

As regards the dating of the grave at Bădragii Vechi, it dates, as mentioned, to the end of the 1st c. - early 2nd c. AD (Bârcă 2001, 340; Bârcă 2006, 172, 283-285; Bârcă 2009, 104).

The grave at Dumeni (T 9 G 13) is a secondary burial in a Bronze Age barrow. The outline of the funerary pit, rectangular, was delimited only at skeleton level, extended, with head to NE. The grave goods included beside the fragmentary pyxis, also a bronze brooch, an amber bead, four golden plates and one leaf, a knife and iron sword with ring by the end of the grip and also 21 threewinged iron arrowheads (Grosu 1988, 84-85, Fig. 3/6-13, 15; Grosu 1990, 58, Fig. 18B; Bârcă 2006, 161, 309-310, Fig. 51).

The brooch is strongly profiled with bilateral spring formed of 12 coils and chord inserted under the bow. The bow is decorated with two knobs: one towards the bow head and the other divides the bow from foot. The foot exhibits a small knob by the end, while the catchplate is trapezoid. The brooch is made of two metal parts and is of small sizes $(2.3 \mathrm{~cm})$.

Brooches of the type are frequently present in the Geto-Dacian settlements from the Siret river basin (Rustoiu 1997, 54), where workshops making such brooches were operational (the settlements of Brad and Poiana, Rustoiu 1997, 20-21). Such brooches are frequent in the Geto-Dacian settlements and fortresses from south-east Transylvania (Rustoiu 1997, 54; Crişan 2000, 140, Pl. 114/8-10, 12), but also in that of Ocnița (Berciu 1981, Pl. 20/1, 71/5, 82/7, 91/6, 11, 102/10-11, 16; Rustoiu 1997, 54, Fig. 62/14-20, 63/7). It was argued that discussed brooches originate in the east-Carpathian Geto-Dacian environment from where they reached also the north-Pontic Sarmatian environment (Bârcă 2006, 129; Bârcă 2011, 18). In addition, in the Sarmatian environment, finds of brooches of the type mainly come from graves in the north-west territories of the Black Sea ${ }^{22}$. Such a brooch also comes from Olbia and other five from late Scythian graves from Crimea (Kropotov 2010, 227-228, no. 16-20).

${ }^{22}$ Except the brooches in the Sarmatian graves from T 3 at Kazanskaya ("Zolotoe kladbishche" cemetery, on the right bank of the Kuban river) (Gushchna and Zasetskaya 1994, 42, cat. no. 22, Pl. 2/22), T 4 at Kolpachki (lower Volga region) (Sergatskov 2004, 109, Fig. 1/21) and G9/1956 at Kobyakovo gorodishche on the right bank of the Danube mouths (Kropotov 2010, 228 , no. 22). 
Chronologically, they emerged most likely by mid/second half of the 1st c. $\mathrm{AD}$ and were fashionable until early $2 \mathrm{nd} \mathrm{c}$. AD. To this period also date the Sarmatian graves with such brooches among the other artifacts classes specific to the period (Bârcă 2006, 129-130; Kropotov 2010, 226, 227-228). In the Sarmatian graves of the first half of the 2 nd c. AD such strongly profiled brooches are missing) included in their furnishing.

As regards T 6 G 1 at Sladkovka, 1977 it dated to the Middle Sarmatian period, alike most graves from this barrow cemetery (Cf. Maksimenko 1998).

The pyxides from presented finds have many parallels mainly in the Roman provincial milieu (Davidson 1952, 136, Pl. 69, nr. 965, 137, Pl. 70, nr. 964; Alföldi 1957, 488, Pl. CXXXIV/14; Pleniscar-Gec 1972, Pl. CCX/6; Petru 1972, Pl. IX/26, XV/1, LXI/4, LXIV/4, LXVIII/24, XCV/13; Marangou 1976, nr. 217, 125, Pl. 64/a, b; Goethert-Polaschek 1977, Pl. 3, 5, 9; Mackensen 1978, Pl. 76/2; Béal and Feugère 1983, 115-126; Groh 1990, 17-23; Groh 1994, 187195; Bíró 1994, 41, 127, Pl. LI-LII; Deschler-Erb 1998, Band 27/1, 179-180, Pl. 44-45, Band 27/2, 332-333; Bíró et al. 2012, 17, 95-98). Such pieces are also found among the finds from the Greek cities, the Bosporan Kingdom, the late Scythian environment of Crimea and that Meotian of the Kuban region (Ivanova 1955, 407, Fig. 2; Sokol'skij 1971, 209, Pl. XXIX/14-15; XXX/14; Peters 1986, 68-70, 143-145, 177, Pl. XIV; Medvedev 2009, 170, Fig. 3/3; Medvedev 2011, Fig. 3/1, 4/12; Zhuravlev and Lomtandze 2002, 77, cat. nr. 289; Gushchina 1982, 26; Vysotskaya 1994, 98, 119, Pl. 5; Puzdrovskij 2007, 155-156, Fig. 133/12-15, 135/1-8, 136/1-2, 6-7; Marčenko and Limberis 2008, 309, cat. nr. 177.3, 181.2, Pl. 185/3, 190/2).

Typologically, bone pyxides from above Sarmatian finds belong, except for the fragmentary specimen from Dumeni, to type $\mathbf{1 a}$ and $\mathbf{1 b}$ in J.-C. Béal and $\mathbf{M}$. Feugère's classification (Béal and Feugère 1983, 116-117, Fig. 2-5). The piece in $T$ $45 \mathrm{G} 1$ at Ust'-Kamenka (Fig. 3/2) belongs to type $\mathbf{1 b}$, while the other complete specimens are similar or close to those ascribed to type 1a. Chronologically, the specimens in type 1a come mainly from 1st c. AD-contexts and complexes, yet they are found as well in the first decades of the 2 nd c. AD. To the second half of the 1 st - first decades/mid 2 nd c. AD date the pyxides that may be ascribed to type $\mathbf{1 b}$ (for the dating of the pyxides of the two types see: Davidson 1952, 136, Pl. 69, nr. 965, 137, Pl. 70, nr. 964; Alföldi 1957, 488, Pl. CXXXIV/14; Pleniscar-Gec 1972, Pl. CCX/6; Petru 1972, Pl. IX/26, XV/1, LXI/4, LXIV/4, LXVIII/24, XCV/13; Marangou 1976, nr. 217, 125, Pl. 64/a, b; Goethert-Polaschek 1977, Pl. 3, 5, 9; Mackensen 1978, Pl. 76/2; Béal and Feugère 1983,115-126; Groh 1990, 17-23; Groh 1994, 187-195; Bíró 1994, 41, 127, Pl. LI-LII; Deschler-Erb 1998, Band 27/1, 179-180, Pl. 44-45, Band 27/2, 332-333; Bíró et al. 2012, 17, 95 - 
98). The latter are notable by the presence of a conical elongated profiled knob or similar to the chess pawn in the centre of the lid (Cf. Béal and Feugère 1983,117, Fig. 3/1b, 5). Concerning the fragmentary piece from the grave at Dumeni(Fig. $4 / 5$ ), decorated with four horizontal lines, double, incised, it must be mentioned that the decoration with incised lines on the body is found on a series of pyxides from the ancient centres from the north of the Black Sea (Cf. Peters 1986, Pl. XIV/9, 17, 20, 21), and also the Roman provincial environment (Cf. Bíró 1994, 41, Pl. LI/442; Bíró et al. 2012, 95, cat. no. 179).

Thus, based on the above notes, it may be concluded that bone pyxides from the discussed Sarmatian graves are mainly Roman products. It is not excluded that some are copies of the latter, being made in local workshops (north-Pontic), like at Panticapaeum ${ }^{23}$, from where, likely, some also reached the Sarmatians, Meotians and late Scythians. All Sarmatian graves with pyxides and other import artifacts among the grave goods as well, date to the second half of the 1st c. - early/first decades of the 2nd c. AD. Even more, those from the area west of the Don are mainly part of the grave group which belonged to the new wave of Sarmarians arriving to the north-Pontic area starting with mid 1st c. AD from regions east of the Don (Bârcă and Symonenko 2009, 178; Simonenko 2008, 30; Simonenko 2011, 111). The graves in this group contain a series of eastern elements and features (for elements specific to the new wave of Sarmatians arriving from the east in the north-Pontic area see Simonenko 2000, 133-144; Bârcă and Symonenko 2009, 99-203; Bârcă 2015, with complete bibliography), also noticeable in the case of graves with pyxides.

A careful analysis of all aspects also shows that these complexes form in the second half of the 1 st c. - first decades of the 2 nd c. AD a local well-marked cultural-chronological horizon.

Last but not least, the pyxides are part of funerary complexes from the period of major inflow of Roman artefacts in the Sarmatian environment, placed between AD 60/70 - 120/130 (stage B2 in the Central-European chronology). It corresponds to the political and military offensive of the Roman empire by the Lower Danube, the establishment of the Roman province of Dacia and also the power increase and more important role played by the Sarmatians in the north and north-west Pontic territories.

As regards the graves with bone pyxides from the north-east Pontic area and the territories east of the Don and Volga, they are from the Middle Sarmatian period and chronologically frame closely or similarly with those from the area

${ }^{23}$ It is argued that in the 1 st $-2 \mathrm{nd}$ c. $\mathrm{AD}$, bone pyxides production spread on general basis in the towns from the north of the Black Sea. Cf. Peters 1986, 68. 
between the Don and Prut. In their case as well, there are many import artefact classes present (brooches, pottery, amphorae, glass or bronze wares, etc.) which are good dating elements, the deceased in some of these graves belonging to the upper class of the Sarmatian society.

Typologically, the bone pyxides from the Sarmatian finds in the north-east Pontic area and the territories east of the Don and Volga may be ascribed, alike those from the west of the Don, to type $\mathbf{1 a}$ and $\mathbf{1 b}$ in J.-C. Béal and M. Feugère's (Béal and Feugère 1983, 116-117, Fig. 2-5) classification. The piece in T 20 at Tiflisskaya (Tbilisskaya) (Fig. 5/4), belongs to type $\mathbf{1 b}$, while the other complete specimens are similar or close to those framed in type $\mathbf{1 a}$.

\section{Bibliography}

Abramova, Maja Pavlovna. 1971. „Zerkala gornyh rajonov Severnogo Kavkaza v pervye veka nashej ery." In Istoriya i kul'tura Vostochnoj Evropy po arkheologicheskim dannym, edited by S. M. Oreshnikova, 121-132. Moskva: Sovetskaya Rossiya.

Alföldi, Mária. 1977. Intercisa II (Dunapentele). Geschichte der Stadt in der Römerzeit. Archaeologia Hungarica, Series nova, 36. Budapest: Akadémiai Kiadó.

Ambroz, Анатолий Константинович. 1966. Fibuly yuga evropejskoj chasti SSSR. Arkheologiya SSSR. Svod Arkheologicheskih Istochnikov D1-30. Moskva: Nauka.

Bârcă, Vitalie. 2001. „Vasele romane de bronz din mormintele sarmatice din spațiul pruto-nistrean.” In Studii de Istorie Antică, edited by Florea, G., G. Gheorghiu, and E. Iaroslavschi, 335-361. Deva: Muzeul Naţional de Istorie a Transilvaniei.

Bârcă, Vitalie. 2006. Istorie şi civilizație. Sarmații in spațiul est-carpatic (sec. I a. Chr. - inceputul sec. II p. Chr.). Cluj-Napoca: Argonaut.

Bârcă, Vitalie. 2006a. Nomazi ai stepelor. Sarmații timpurii în spaţiul nord-pontic (sec. II-I a. Chr.). Biblioteca Ephemeris Napocensis 6. Cluj-Napoca: Argonaut.

Bârcă, Vitalie. 2009. „Câteva considerații privind vasele metalice de import din mediul sarmatic nord-pontic." In Near and Beyond the Roman Frontier. Proceedings of a colloquium held in Târgovişte, 16-17 October 2008, edited by O. Ţentea and I. C. Opriş, 85-124. Supplementum Cercetări Arheologice 16. Bucureşti: Conphys.

Bârcă, Vitalie. 2011. „The fibulae in the North-Pontic Sarmatian Environment (1st C - first half of the 2nd C CE)." Ephemeris Napocensis XXI, 2011: 7-35. 
Bârcă, Vitalie. 2014. Sarmatian vestiges discovered south of the Lower Mures River. The graves from Hunedoara Timişană and Arad. Cluj-Napoca: Mega.

Bârcă, Vitalie. 2014a. „Rectangular Mirrors in the Sarmatian Environment. Notes on their origin and the dating of the graves containing them." In Archäologische Beiträge - Gedenkschrift zun hundertsten Geburtstag von Kurt Horedt, edited by S. Cociș, 49-63. Cluj-Napoca: Mega.

Bârcă, Vitalie. 2015 „The reinterpretation of the Sarmatian finds from the Romanian Plain (I)." Journal of Ancient History and Archaeology 2/1: 35-71 (DOI: 10.14795/j.v2i1.105).

Bârcă, Vitalie. 2016. „A disk mirror recently discovered South the Lower Mureș." Journal of Ancient History and Archaeology 3/3: 55-61 (DOI:10.14795/j. v3i3.198).

Bârcă, Vitalie. 2017. "Notes on the metal pyxides recently discovered in the Sarmatian environment south the Lower Mureș River." Plural. History-Culture-Society vol. 5, nr. 2: 101-123.

Bârcă, Vitalie and O. Symonenko. 2009. Călăreții stepelor. Sarmații în spațiul nord-pontic. Cluj-Napoca: Mega.

Berciu, Dumitru. 1981. Buridava dacică. Bucureşti: Editura Academiei Republicii Socialiste România.

Bespalyj, E. I. 1992. „Kurgan sarmatskogo vremeni u g. Azova.” Sovetskaya Arkheologiya 1: 175-191.

Bespalyj, E. I. and S. I. Luk'yashko. 2018. Drevnee naselenie mezhdurech'ya Dona i Kagal'nika. Kurgannyj mogil'nik u s. Novoaleksandrovka, Vol. 2 Rostov-na-Donu: Izdatel'stvo Yuzhnogo nauchnogo tsentra Rossijskoj Akademii Nauk.

Béal, Jean-Claude and Michel Feugère. 1983. "Les pyxidesgallo-romainesenosde Gauleméridionale.” Documents d'Archéologie Méridionale 6: 115-126.

Bíró, Maria T. 1994. The Bone Objects of the Roman Collection. In memoriam Gizella Erdélyi. Catalogi Musei Nationalis Hungarici, Series Archaeologica II. Budapest: Magyar Nemzeti Múzeum.

Bíró, Maria T., Alice M. Choyke, Lóránt Vass, and Ádám Vecsey. 2012. Aquincumicsonttárgyak/Bone Objects in Aquincum. Aquincumi Múzeumgyüjteménye 2. Aquincum Collection 2. Budapest: Aquincumi Múzeum.

Bozsik, K. 2003. „Szarmata sírok a Kiskundorozsma-subasai 26/78. lelőhelyen." In Úton-útfélen. Múzeumi kutatások az M5 autópálya nyomvonalán, edited by Cs. Szalontai, 97-106. Szeged: Móra Ferenc Múzeum.

Crişan, Viorica. 2000. Dacii din estul Transilvaniei. Sfântu Gheorghe: Carpatii Răsăriteni. 
Davidson, Gladys R. 1952. Corinth. Results of Excavations conducted by the American School of Classical Studies at Athens, XII, The Minor Objects. Princeton: American School of classical studies at Athens.

Deschler-Erb, Sabine. 1998. Römische Beinartefakteaus Augusta Raurica. Rohmaterial, Technologie, Typologie und Chronologie. Forschungen in Augst 27. Augst: Römermuseum.

Firsov, Kirill. B. 1998. „Kurgan sarmatskogo vremeni v Kalmykii.” Arheologhicheskij sbornik. Trudy Gosudarstvennogo Istoricheskogo muzeya 96: 128-136.

Glukhov, Aleksandr A. 2003, "Tipologiya i khronologiya zerkal srednesarmatskogo vremeni (po materialam mezhdurech'ya Volgi i Dona)“, Nizhnevolzhskij arkheologicheskij vestnik 6, 89-102.

Goethert-Polaschek, Karin. 1977. Katalog der römischen Gläser des Rheinischen Landesmuseums Trier. Trierer Grabungen und Forschungen 9. Mainz: Philipp von Zabern.

Groh, Stefan. 1990, "Römische Bein- und Elfenbeinschnitzereinen mit Erotendarstellungen.” Diplomarbeit, Graz.

Groh, Stefan. 1994. "Ein Elfenbeinrelief aus der Tunnelhöhle am Kugelstein in der Steiermark.” Archäologisches Korrespondenzblatt 24, 2: 187-195.

Grosu, Vasilij I. 1988. „Sarmatskie pamyatniki Srednego Poprut'ya.” In Arheologicheskie issledovaniya v Moldavii v 1983 g., edited by G.F. Chebotarenko, 79-91. Kishinev: Ştiința.

Grosu, Vasilij I. 1990. Khronologiya pamyatnikov sarmatskoj kul'tury Dnestrovsko-Prutskogo mezhdurech'ya. Kishinev: Știința..

Gushchina, Irina I. 1982. „O lokal'nykh osobennostyakh kul'tury naseleniya Bel'bekskoj doliny Kryma v pervye veka n. e.” Trudy Gosudarstvennogo Istoricheskogo muzeya 54. Arkheologicheskie issledovaniya na yuge Vostochnoj Evropy II: 20-30.

Gushchina, Irina. I. and I. P. Zasetskaya. 1994. „Zolotoe kladbishche” Rimskoj epohi v Prikuban'e. Sankt-Peterburg: Farn.

Hayes, John W. 1985. „Sigillate Orientali.” In Enciclopedia dell'arte antica classica e orientale. Atlante delle forme ceramiche II. Ceramica fine romana nel bacino Mediterraneo (tardoellenismo e primo impero), 1-96. Roma: Istituto della Enciclopedia Italiana.

Istvánovits, Eszter and Valéria Kulcsár, 1993, „Tükrök a császárkori és a kora népvándorlás kori barbár népeknél a Kárpát-medencében.” A Herman Ottó Muzeum Ėvkönyve XXX-XXXI, 2: 9-58.

Isings, Clasina. 1957. Roman Glass from dated finds. Groningen-Djakarta: J. B. Wolters. 
Javanova, A. I. 1955. „Khudozhestvennye izdeliya iz dereva i kosti.” In Antichnye goroda Severnogo Prichernomor'ya. Ocherki istorii i kul'tury edited by V. F. Gajdukevich, and M. I. Maksimova, 400-436. Moskva-Leningrad: Izdatel'stvo Akademii nauk SSSR.

Khazanov, Anatolij M. 1963. „Genezis sarmatskih bronzovyh zerkal.” Sovetskaya Arkheologiya 4: 58-71.

Knipovich, Tat'jana N. 1952. „Krasnolakovaya keramika pervyh vekov nashej ery iz raskopok Bosporskoj ekspeditsii v 1935-1940.” Materialy i issledovaniya po arkheologii 25: 289-326.

Kostenko, V. I. 1977. „Sarmatskie pamyatniki v materialakh archeologicheskoj ekspeditsii DGU.” In Kurgannye drevnosti stepnogo Podneprov' ja III - I tys. do. n. e., edited by I. F. Kovaleva, 114-137. Dnepropetrovsk: Izdatel'stvo DGU.

Kostenko, V. I. 1993. Sarmaty v Nizhnem Podneprov'e (po materialam Uşt'-Kamenskogo mogil'nika). Dnepropetrovsk: Izdatel'stvo DGU.

Kovpanenko, Galina T. 1986. Sarmatskoe pogrebenie I v. n. e. na Yuzhnom Buge. Kiev: Naukova dumka.

Kropotkin, Vladislav V. 1970. Rimskie importnye izdeliya v Vostochnoj Evrope (II v. do n. e. - V v. n. e.). Arkheologiya SSSR. Svod Arkheologicheskih Istochnikov D1-27. Moskva: Nauka.

Kropotov, Victor V. 2010. Fibuly sarmatskoj epokhi. Kiev: ADEF-Ukraina.

Kunina, N. and N. Sorokina, 1972, „Steklyannye bal'zamarii Bospora.” Trudy Gosudarstvenogo Ermitazha 13: 146-177.

Kurchatov, Sergej and Valerij Bubulici, 2003. „Sarmatskoe pogrebenie iz kurgana u s. Oloneshty - 40 let spustya." In Interferențe cultural-cronologice in spațiul nord-pontic, edited by E. Sava, 285-312. Chişinău: Institutul de Arheologie şi Etnografie.

Lloyd-Morgan, Glenys. 1977. „Mirrors in Roman Britain.” In Roman Life and Art in Britain, edited by J. Munby and M. Henig, 231-252, British Archaeological Reports 41 (II). Oxford: B.A.R.

Lloyd-Morgan, Glenys. 1980. „Roman Mirrors and Pictish Symbol.” In A note on Trade and Contact. Roman Frontier Studies 1979, edited by W. S. Hanson, and L. J. F. Keppie, 97-106. Papers presented of the 12th International Congress of Roman Frontier Studies. British Archaeological Reports, International Series 71 (I). Oxford: B.A.R.

Lloyd-Morgan, Glenys. 1981. „Roman Mirrors and the Third Century.” In The Roman West in Third Century: Contributions from Archaeology and History, edited by A. King and M. Henig, 145-157. British Archaeological Reports, International Series109. Oxford: B.A.R. 
Lloyd-Morgan, Glenys. 1981a. The Mirrors: Description of the Collections in the Rijksmuseum G. M. Kam at Nijmegen IX. Nijmegen: Ministry of Culture, Recreation and Social Welfare.

Lund Hansen, Ulla. 1987. Römischer Import im Norden. Warenaustausch zwischen dem Römischen Reich und dem freien Germanien während der Kaiserzeit unter besonderer Berücksichtigung Nordeuropas. Nordiske Forditsminder, Serie B 10. København: Det Kongelige nordiske Oldskriftselskab.

Mackensen, Michael. 1978. Das römische Gräberfeldauf der Keckwiese in Kempten, I. Gräber und Grabanlagen des 1. und 4. Jahrhunderts. Materialhefte zur bayerischen Vorgeschichte 34, Kallmünz/Opf: Verlag Michael Lassleben.

Maksimenko, Vladimir. E. 1983. Savromaty i sarmaty na Nizhnem Donu. Rostov-na-Donu: Izdatel'stvo Rostovskogo universiteta.

Maksimenko, Vladimir. E. 1998. Sarmaty na Donu (arkheologiya i problemy etnicheskoj istorii). Donskie drevnosti 6. Azov: Azovskij kraevedcheskij muzej.

Marangou, Lila. 1976. Bone Carving from Egypt, I. Graeco-Roman Period. Tübingen: Ernst Wasmuth.

Marchenko, Ivan I. 1996. Siraki Kubani (po materialam kurgannyh pogrebenij Nizhnej Kubani. Krasnodar: Kubanskij gosudarstvennyj universitet.

Marčenko, Ivan I. and Natal'ja Ju. Limberis. 2008. Römische Importe in sarmatischen und maiotischen Denkmälern des Kubangebietes, 265-400, Pl. 1-222. In: Römishe Importe in sarmatischen und maiotischen Gräbern zwischen Unterer Donau und Kuban edited by Aleksandr Simonenko, Ivan I. Marčenko and Natal'ja Ju. Limberis, Archäologie in Eurasien 25. Mainz: Philipp von Zabern.

Medvedev, Aleksandr P. 2009. „Dva pozdneantichnykh sklepa Vostochnogo nekropolya Fanagorii”. In Gunny, goty i sarmaty mezhdu Volgoi i Dunaem, edited by A. Furas'ev, 167-182. Sankt-Peterburg: Fakul'tet filologii i iskusstv SPbGU.

Medvedev, Aleksandr P. and K. Yu Yefimov. 1986. „A Sarmatian barrow with Roman and Chinese imports in the Middle Don Region”. In Roman Imports in the Lower Don Basin, edited by B. A. Raev, British Archaeological Reports, International Series 278, 83-84. Oxford: B.A.R..

Melyukova, Anna. I. 1962. „Sarmatskoe pogrebenie iz kurgana u s. Oloneshty (Moldavskaya SSR)", Sovetskaya Arkheologiya 1: 195-208.

Moshkova, Marina G. 1989. „Srednesarmatskaya kul'tura”. In Arkheologiya SSR. Stepi Evropejskoj chasti SSR v skifo-sarmatskoe vremea, edited by A. I. Melyukova, 177-191. Moskva: Nauka.

Mordvintseva, Valentina. and Mikhail Trejster 2007. Proizvedeniya torevtiki $i$ yuvelirnogo iskusstva $v$ Severnom Prichernomor'e 2 v. do n. e. -2 v. n. e., I-III. Simferopol'-Bonn: Tarpan. 
Opait, Andrei 1980. „Considerații preliminare asupra amforelor romano-bizantine din Dobrogea”. Peuce VIII : 291-327.

Párducz, Mihály. 1941. A szarmatakor emlékei Magyarországon I/Denkmäler der Sarmatenzeit Ungarns I. Archaeologia Hungarica XXV. Budapest: AkadémiaiKiado.

Párducz, Mihály. 1950. A szarmatakor emlékei Magyarországon III/Denkmäler der Sarmatenzeit Ungarns III. Archaeologia Hungarica XXX. Budapest: Akadémiai Kiado.

Párducz, Mihály. 1950a. „Szarmata sírok Tápiószelén”. Archeológiai Értesitö 77: 67-71.

Peters, B. G. 1986. Kostoreznoe delo v antichnykh gosudarstvakh Severnogo Prichernomor'ya. Moskva: Nauka.

Petrovszky, Richard. 1993. Studien zu römischen Bronzegefäßen mit Meisterstempeln. Buch am Erlbach: M. L. Leidorf.

Petru, Sonja. 1972. Emonske nekropole. Odkrite med leti 1935-1960. Ljubliana: Narodni muzej.

Pleniscar-Gec, L. 1972. Severno Emonsko Grobisce. Ljubliana: Narodni muzej.

Puzdrovskij, Aleksandr. E. 2007. Krymskaya Skifiya II v. do n. e. - III v. n. e. Pogrebal'nye pamyatniki. Simferopol': Biznes-Inform.

Robinson, Henry. S. 1959. Pottery of the Roman Period. Chronology. The Athenian Agora. Princeton-New Jersey: American School of Classical Studies at Athens.

Rustoiu, Aurel. 1996. Fibulele din Dacia preromană (sec. II î.e. n. - I e.n.). Bucureşti: Vavila Edinf.

Senigova, Taisija. N. 1956. „Otchet o rabote Zapodno-Kazakhstanskoj arkheologicheskoj ekspeditsii v 1953 g.”. Trudy Instituta Istorii i Arkheologii Kazakhskoj SSSR I, 140-156.

Sergatskov, Igor' V. 2004. „K khronologii srednesarmatskoj kul'tury Nizhnego Povolzh'ya”. In Sarmatskie kul'tury Evrazii: problemy regional'noj khronologii, edited by B. A. Raev. Doklady k 5-j mezhdunarodnoj konferentsii "Problemy sarmatskoj arkheologii i istorii”, 107-116. Krasnodar: OOO firma NSS.

Shelov, Dmitrij B. 1978, „Uzkogorlye svetloglinyanye amfory pervyh vekov nashej ery. Klassifikaciya i khronologiya”. Kratkie soobshcheniya Instituta arkheologii 156: 16-21.

Simonenko, Aleksandr V. 1993, Sarmaty Tavrij. Kiev: Naukova dumka.

Simonenko, Aleksandr V. 2000. „Mogilnik Dneprozavodstroj i sarmatskie pamyatniki "vostochnoj volny"v Severnom Prichernomor'e". Nizhnevolzhskij arkheologicheskij vestnik 3: 133-144. 
Simonenko, Aleksandr V. 2004. „Khronologiya i periodizatsiya sarmatskih pamyatnikov Severnogo Prichernomor'ya”. In Sarmatskie kul'tury Evrazii: problemy regional'noj khronologii, edited by B. A. Raev, Doklady k 5-j mezhdunarodnoj konferentsii "Problemy sarmatskoj arkheologii i istorii", 134-173. Krasnodar: OOO firma NSS

Simonenko, Aleksandr V. 2008. „Römische Importe in sarmatischen Denkmälern des nördlichen Schwarzmeergebietes", In A. Simonenko, I. I. Marčenko and Natal'ja Ju. Limberis, Römishe Importe in sarmatischen und maiotischen Gräbern zwischen Unterer Donau und Kuban, Archäologie in Eurasien 25, 1-94, Pl. 1-168. Mainz: Philipp von Zabern.

Simonenko, Aleksandr V. 2011. Rimskij import u sarmatov Severnogo Prichernomor'ya. Sankt-Peterburg: Nestor-Istoriya.

Simonenko, Aleksandr V. and Boris I. Lobaj 1991. Sarmaty Severo-Zapodnogo Prichernomor'ya v I v. n.e. (pogrebenie znati u s. Porogi) Kiev: Naukova dumka.

Skripkin, Anatolij S. 1990. Aziatskaya Sarmatiya. Problemy khronologii i eӗ istoricheskij aspekt Saratov: Izdatel'stvo Saratovskogo universiteta.

Skripkin, Anatolij S. and Valerij M. Klepikov 2004. „Khronologiya rannesarmatskoj kul'tury Nizhnego Povolzh'ya. In Sarmatskie kul'tury Evrazii: problemy regional'noj khronologii, edited by B. A. Raev, Doklady k 5-j mezhdunarodnoj konferentsii "Problemy sarmatskoj arkheologii i istorii", 95-116. Krasnodar: OOO firma NSS

Sokol'skij, N. I. 1971. Derevoobrabatyvayushchee remeslo v antichnykh gorodakh Severnogo Prichernomor'ya. Materialy i issledovaniya po arkheologii SSSR 178, Moskva: Nauka.

Vaday, Andrea. 1980. „Sarmatisches Gräberfeld in Törökszentmiklós, Surján”. Mitteilungen des Archäologischen Instituts der Ungarischen Akademie der Wissenscheften 8-9, 1978-1979: 57-69, 309-324.

Vaday, Andrea H. 1989. Die sarmatischen Denkmäler des Komitats Szolnok. Antaeus 17-18, 1988-1989. Budapest: Archäologisches Inst. der UAW.

Vaday, Andrea and Béla Miklós Szőke 1983. „Szarmata temetö és gepida sír Endrőd-Szujókereszten" Communicationes Archaeologicae Hungaricae: 79-132.

Vnukov, Sergej Yu. 2003. Prichernomorkie amfory I v. do n.e. - II v. n.e. (morfologiya). Moskva: Institut arkheologii Rossijskoj akademii nauk.

Vnukov, Sergej Yu. 2006. Prichernomorkie amfory I v. do n. e. - II v. n. e., II, Petrografija, hronologija, problemy torgovli. Sankt-Peterburg: Aletejya.

Vysotskaya, Tat'jana N. 1994. Ust'-Alminskoe gorodishche i nekropol'. Kiev: Kievskaya Akademiya Evrobiznesa. 
Vyaz'mitina, Marija I., Varvara A. Ill'ins'ka, E. F. Pokrovs'ka, Oleksij. I. Terenozhkin, and Galina T. Kovpanenko 1960. „Kurgany bilya s. Novo-Pilipivki i radgospu Akkermen"”. Arheologichni pam'yatki URSR VIII: 22-135.

Zhuravlev, Dmitrij V. and Gheorhij. A. Lomtadze 2002. „Izdeliya iz gipsa i kosti”. In Na krayu ojkumeny. Greki i varary na severnom beregu Ponta Evksinskogo, edited by Dmitrij V. Zhuravlev, 76-78. Moskva: Gosudarstvennyj Istoricheskij Muzej.

\section{Pixidele din os din mediul sarmatic nord și nord-vest pontic. Observații pe marginea origini și datărilor}

\section{Rezumat}

Subiectul articolului de față îl constituie analiza pixidelor din os descoperite într-o serie de morminte sarmatice din nordul şi nord-vestul Mări Negre. Fără a avea pretenții de exhaustivitate, se încearcă o prezentare a mormintelor în care acestea au fost descoperite, dar și a mediilor culturale unde au fost utilizate piese de toaletă similare. În urma analizei, autorul concluzionează că pixidele din os descoperite în mormintele sarmatice din teritoriul nord-pontic sunt, $\mathrm{cu}$ precădere, produse romane. $\mathrm{Cu}$ toate acestea, nu se exclude ca unele dintre pixide să fi fost imitaţii ale celor dintâi, fiind realizate în atelierele locale (nord-pontice). Autorul constată că toate mormintele sarmatice în care s-au descoperit pixide se datează, judecând după componența inventarelor acestora, în a doua jumătate a sec. I - începutul/primele decenii ale sec. II p. Chr. De asemenea s-a remarcat că acestea fac parte, cu precădere, din cadrul grupului de morminte ce au aparținut noului val de sarmați veniți în spațiul nord-pontic începând cu mijlocul sec. I p. Chr. de la est de Don și că formează în doua jumătate a sec. I - primele decenii ale sec. II p. Chr. un orizont cultural-cronologic local bine evidențiat. Nu în ultimul rând autorul remarcă că pixidele fac parte din complexe funerare din perioada cu aflux major de artefacte romane în mediul sarmatic, situată în intervalul cronologic cuprins între anii 60/70 120/130 p. Chr.

Cuvinte-cheie: sarmați, pixide, artefacte, importuri, morminte, spațiul nord și nord-vest pontic, Imperiul Roman

\section{Vitalie Bârcă,}

Institute of Archaeology and Art History of Cluj-Napoca, Romania.

Email: vitalie_barca@yahoo.com 